\title{
KOREAN CONSTITUTIONAL COURT AND CONSTITUTIONALISM IN POLITICAL DYNAMICS: FOCUSING ON PRESIDENTIAL IMPEACHMENT
}

\author{
Jin Wook Kim ${ }^{1}$ \\ The Constitutional Court of Korea, Seoul, Korea \\ jwkimlaw@gmail.com
}

\begin{abstract}
The Constitutional Court of Korea, which should be a product of the June Democracy Movement in 1987, has transformed Korea's constitutionalism ever since its inception. The recent two impeachment cases decided respectively in 2004 against President Roh and in 2017 against President Park might be classic examples of how the state institutions including the Court interact with other institutions in a very political case in terms of political dynamics. In the impeachment case against President Roh, the Court positioned itself strategically by establishing the 'grave violation of law' rationale, where it sided with the impeaching parliament by finding three counts of violations of law but dismissed the case in its entirety through the operation of the 'grave violation of law'. In the impeachment case against President Park, the Court basically followed the grave violation logic but reached a different conclusion to remove the President, which might be another strategic position taken by the Court, which is in line with the will of the super-majority of the Korean public. This paper aims to discuss how the Constitutional Court has developed its strategic position in terms of political dynamics, by analyzing the two presidential impeachment cases.

Key Words: Grave Violation of Law, Korean Constitutional Court, Presidential Impeachment.

Head of Education Department, Constitutional Research Institute, The Constitutional Court of Korea; former Head of Human Rights Research Department, Constitutional Research Institute, The Constitutional Court of Korea (February 2016-January 2018).
\end{abstract}




\section{INTRODUCTION}

The June Democracy Movement ${ }^{2}$ that generated massive nationwide demonstrations in Korea from June 10 to June 29 in 1987 protesting against the prolonged rule of the authoritarian regime was a landmark in Korea's constitutionalism. It brought about June $29^{\text {th }}$ Declaration by then ruling party's presidential candidate Roh Tae-Woo ${ }^{3}$, in which he promised a direct presidential election and peaceful transfer of state power through constitutional amendment. Roh's concession was a response to civil society's long request for people's direct voting in presidential election, ultimately bringing down a longstanding military regime after all. ${ }^{4}$ Among the key features of the 9th amendment of the Korean Constitution in 1987 was the introduction of the independent Constitutional Court system.

Under the Yushin Constitution, promulgated in 1972 by then President Park Chung-Hee ${ }^{5}$ and under the 1980 Constitution, promulgated after Chun Doo-Hwan rose to power in a military coup, jurisdiction for constitutional adjudication was granted to the Constitutional Committee and constitutionality review before the Committee should be requested by the Supreme Court of Korea, which failed to make a single request before the Committee. ${ }^{6}$ Prior to the Constitutional Committee system, the Supreme Court of Korea had jurisdiction over constitutionality review as well as over other general legal matters, like the U.S. Supreme Court. ${ }^{7}$

With regard to the constitutional review system before the establishment of the Constitutional Court in 1988, Korea's constitutionalism in general and constitutional adjudication in particular had remained only at a nominal level

It is also called as the 6.10 Democracy Movement.

3 June 1oth's announcement by President Chun Doo-Hwan's military regime that it nominates Roh Tae-Woo, Chun's friend and former military general, as his successor triggered the Movement.

4 Under the 1980 Korean Constitution, Korean president shall be elected indirectly by 5,00o members of the Electoral College, elected by the Korean people only for the purpose of presidential election.

5 Park Chung-Hee rose to power in 1961 through a military coup and since then had led Korea until he was assassinated by KCIA director Kim Jae-Gyu on October 26, 1979.

6 Constitutional Court of Korea, Thirty years of the Constitutional Court of Korea (South Korea: Constitutional Court of Korea, 2018), 83-89.

7 Ibid., 64-67. Korea then followed the American model of judicial review in which the power to review the constitutionality of statutes is diffused throughout the courts as a decentralized model of constitutional adjudication. 
so as to declare only four statutes unconstitutional for the past 40 years. ${ }^{8}$ For this reason, the political circle did not expect much from the Constitutional Court when it was established in September, 1988. Contrary to such expectations, however, the Korean Constitutional Court began to actively engage Korean society by producing many meaningful decisions from the beginning. 9 The Court has nullified as many as more than 580 statutes to date by its en banc decisions, ${ }^{10}$ often to the embarrassment of the ruling party and its rival institution, the Supreme Court of Korea. ${ }^{11}$

With the establishment of the Constitutional Court of Korea, it is safe to say that the Korean public is now having an effective mechanism to enforce the Constitution, and one of the important instruments to implement the constitutional norms is the constitutional complaint system, in which individuals may file complaints directly before the Court when their constitutional rights are violated, ${ }^{12}$ or their requests for adjudication on constitutionality of a statute in a pending lawsuit are dismissed by a court. ${ }^{13}$ Constitutional complaint was also one of the main reasons why an independent Constitutional Court system could be introduced through the constitutional amendment in $1987 .{ }^{14}$

During its history, 2004 was an unforgettable year for the Constitutional Court, in which it became deeply involved in political dynamics of Korean society, and produced two landmark decisions affecting the Korean political

8 Lee, Kang-Kook, "The Past and Future of Constitutional Adjudication in Korea," Current Issues in Korean Law (The Robbins Collection Berkeley Law: University of California at Berkeley, 2014), 10.

9 The Constitutional Court of Korea has jurisdiction over the following matters: 1) Constitutionality of a statute upon the requests by the courts, 2) Impeachment, 3) Dissolution of a political party, 4) Competence disputes between state agencies, between state agencies and local governments, and between local governments, and 5) Constitutional complaints.

10 This statistics is from the Court's official website: www.ccourt.go.kr.

11 Kyong-Whan Ahn, "The influence of American Constitutionalism on South Korea," Southern Illinois Law Journal 22 (2017), 76.

12 According to Article 68 Section 1 of the Constitutional Court Act, any person whose constitutional rights have been violated by exercise or non-exercise of government institutions, excluding court judgments, may request adjudication on constitutional complaint before the Constitutional Court. This type of constitutional complaint is called Article 68(1) constitutional complaint.

${ }_{13}$ This unprecedented type of constitutional complaint is called Article 68(2) constitutional complaint and under this system, "any party to an ordinary court proceeding has recourse to the Constitutional Court to receive a final decision on the constitutionality of the statutes" if the request for constitutionality review was dismissed by the court of original jurisdiction. Lee, Kang-Kook, "The Past and Future of Constitutional Adjudication in Korea," 13 .

14 Constitutional Court of Korea, Thirty years of the Constitutional Court of Korea, 95-96. 
dynamics tremendously. One was the decision on the impeachment motion by the parliament against President Roh, decided on May 14, 2004, and the other was the decision on Korea's capital city relocation, ${ }^{15}$ decided on October 21, 2004, ${ }^{16}$ and in the presidential impeachment case, the Court stressed that impeachment adjudication is a system designed to protect and maintain the Constitution/constitutional order from violations by high-ranking government officials of the executive and/or the judicial branch. ${ }^{17}$

From late October 2016 to March 2017 many South Koreans took to the street and staged a series of protests with candle lights in hands, denouncing a political scandal involving President Park Geun-Hye herself and calling for her resignation or impeachment. That is now called the Candlelight Struggle or 2016-2017 South Korean Protests, and is regarded as one of the key driving forces of President Park's impeachment.

This paper aims to assess Korea's constitutionalism in relation to the Constitutional Court of Korea and especially in the context of political dynamics. Since constitutional governance should honor a separation of powers among state institutions (i.e. the legislature, the executive, and the judicial branch) and should keep checks and balances between those institutions, and presidential impeachment in which the legislature tries to remove the head of the executive

15 The case was about relocation of the administrative functions of Korea's capital from Seoul to Chung-Cheong Province, one of President Roh's key campaign pledges. After being elected as president, President Roh and the ruling party introduced a Special Act on the Construction of a New Administrative Capital ("Special Act"), but the Constitutional Court held the Special Act unconstitutional. The Court said that Seoul has been the capital of Korea for over 600 years and Seoul's status as the nation's capital has become a customary constitutional norm, thus a constitutional amendment, not an enactment of a special law must be required for the relocation of the capital. Ibid., 283-291.

${ }_{16}$ In the wake of the ruling of the capital relocation case, some political scientists heavily criticized that the Court's decision is a classic example of a political decision by the judiciary or judicialization of politics, even deploring that an "imperial judiciary" has now come in Korea.

Choi' Jang-Gip, Commentary on The Korean edition of How Democratic is the American Constitution, by Robert Dahl (Humanitas, 2004), 49-57.

17 The Court elaborated further by saying, "Article 65 of the Korean Constitution includes the President in defining 'public officials' who are subject to impeachment, having a discernible position that even the President who has been elected by the Korean public, thus being endowed with democratic legitimacy directly from the public, may be impeached in order for the preservation of the Constitution or the constitutional order and that even a political chaos that might be caused by the removal decision of the President should be deemed as an inevitable cost for democracy for the purpose of protecting 'the basic order of liberal democracy'. Therefore the system that subjects the President to impeachment is for the realization of the rule of law, in which every person is under the law without exception and even the state power's holder such as president cannot be above the law." Constitutional Court of Korea, Korean Constitutional Court Decisions ("KCCR") Vol. 16-1 (Constitutional Court of Korea, 2004), 632-633. 
must involve political dynamics among state institutions. In this vein, it is worth studying Korea's recent two presidential impeachment cases, among which the first was President Roh Moo-Hyun's impeachment in 2004 and the second was the impeachment of President Park Geun-Hye in 2016-2017, and this study is with a goal to understand how the Constitutional Court interacts with other state institutions in the context of political dynamics, by analyzing the two cases.

\section{ANALYSIS OF THE PRESIDENT ROH IMPEACHMENT CASE}

\subsection{Government Structure and Impeachment Clause in Korea}

The Korean government is structured based upon separation of powers principle, like other modern governments. It has mostly had a presidential system of government since the founding Constitution of 1948, with the exception of the short-lived parliamentary cabinet system under the third and fourth revisions of the Constitution from mid-1960 to late 1962.

The Korean Constitution has had an impeachment clause against the president since its founding Constitution and the state institution that initiates the impeachment is the National Assembly. ${ }^{18}$ The impeachment clause in the current Constitution reads as follows.

Article 65 (Impeachment)

(1) In case the president, the prime minister, members of the State Council, ministers, justices of the Constitutional Court, judges, members of the National Election Commission, the chairperson and members of the Board of Audit and Inspection, and other public officials designated by statutes have violated the Constitution and/or other statutes in the performance of official duties, the National Assembly may pass motions for their impeachment.

(2) A motion for impeachment prescribed in paragraph (1) may be proposed by one third or more of the total members of the National Assembly, and shall require a concurrent vote of a majority of the total members of the National Assembly for passage: Provided, that a motion for the impeachment of the president shall be proposed by a majority of the total members of the National Assembly and approved by two thirds or more of the total members of the National Assembly.

Korea has a unicameral parliamentary system. 
(3) Any person against whom a motion for impeachment has been passed shall be suspended from exercising his/her power until the impeachment has been adjudicated.

(4) A decision on impeachment shall not extend further than removal from public office: Provided, that it shall not exempt the person impeached from civil or criminal liability.

\subsection{Background of Roh Impeachment Case}

Roh Moo-Hyun was elected as president in December 2002 and took office in February 2003 with a five-year term with no possibility of renewal. From the beginning of his term President Roh had to face opposition from the Grand National Party (GNP) with the majority seats (149 seats) in the National Assembly. To make the matter worse, the President's own party, the Millennium Democratic Party (MDP) had its internal power struggle and 40 pro-Roh lawmakers defected from MDP and formed a new party, the Uri Party with 47 seats in November 2003, leaving remaining MDP lawmakers (63 members) bearing a grudge against the President and causing them to share anti-Roh sentiments with GNP lawmakers. ${ }^{19}$

As the general election, scheduled for mid-April 2004, was approaching, President Roh made some election related remarks with the hope of getting the majority seats for the Uri party in the National Assembly, which both GNP and MDP members of the parliament vehemently resisted. They became bitter, threatening to impeach the President, and began to form an anti-Roh coalition, which in turn became a driving force of President Roh's impeachment.

On February 18, 2004, the President said at a press conference with six news media organizations, “.... I simply cannot say what will happen if the quorum to block a constitutional amendment attempt by the opposition succeeds in this election." ${ }^{20}$ He added at a press conference with the Korean Network Reporters Club, which was broadcast nation-wide on February 24, 2004, "I am expecting that the Korean public will support the Uri party overwhelmingly, and "I intend to do everything that is legally allowed if it may lead to the party's win in this

\footnotetext{
19 Youngjae Lee, "Law, Politics, and Impeachment: The Impeachment of Roh Moo-Hyun from a Comparative Constitutional Perspective," American Journal of Comparative Law 53 (2005): 408-409.

20 It means that the opposition continues to take the super-majority in the parliament.
} 
election," and, "Once the public elected me as president, they should give me their support in this election as well, in order for me to continue my job as president. Otherwise, I may step down from the presidency if they decide to give me a disapproval vote in this election." ${ }^{21}$

In early March, the National Election Commission sent a warning letter to President Roh, mentioning his above remarks and requesting that he should remain neutral in the upcoming general election as a public official, and the opposition demanded an apology from the President for his remarks, with threats to file impeachment against him. In response, President Roh said at a press conference on March 11 that he is not persuaded by the Commission's view that his support for the ruling party had violated political neutrality. ${ }^{22}$

A day later on March 12, 2004, the National Assembly passed a motion to impeach President Roh with 193 supporting votes for his impeachment out of 273 total members and the office of the President became suspended immediately according to Article 65 Section 3 of the Korean Constitution. ${ }^{23}$

\subsection{Court's Findings on the President's Violations}

During the impeachment trial at the Constitutional Court, the lawyers for the President asserted that in order to impeach the sitting president, there must be a grave and clear violation of law, not just a violation of law, but the lameduck parliament rebutted that the ground for impeachment should be any act in violation of the Constitution and/or statutes, and should not be limited to a grave violation of law. The National Assembly further insisted that not only an act in violation of the Constitution and/or statutes by the President but his/ her political incompetency and decision making errors should also constitute a ground for impeachment, and that the parliament, which is a democratically elected institution, should be the final arbiter of whether the President's violation of law amounts to his/her removal decision, not the Constitutional Court, and added that the Court's job should be limited to whether the specific violation

\footnotetext{
Constitutional Court of Korea, KCCR Vol. 16-1 (2004), 634 .

Youngjae Lee, "Law, Politics, and," 410-411.

Constitutional Court of Korea, Thirty years of the Constitutional Court of Korea, 283-284.
} 
of law constituting the ground for impeachment exists, and the constitutionality or legality of the impeachment proceeding. ${ }^{24}$

The Court delivered its final decision on May 14, 2004 a month after the April 15th general election, in which President Roh's ruling party more than tripled its seats in the National Assembly from 47 to 152 seats (out of 299 total seats) while the GNP party retained 121 seats (from 149 seats before) and the MDP party secured only 9 seats (from 63 seats before). ${ }^{25}$

The Constitutional Court found that President Roh violated the Constitution and/or other statutes on the following three instances, but dismissed the case after all.

\subsubsection{Election Related Remarks}

The basic facts about the contents of the President's election related remarks are described in the above background of the case (basically remarks on Feb. 18 and Feb. 24, 2004 by the President) and the Court found that the President's remarks violated his duty to maintain political neutrality in elections.

In its rationale, the Court cited Article 7 of the Constitution, ${ }^{26}$ and interpreted it as follows: the Constitution mandates that state institutions should serve the entire population and act neutrally in a competition among political parties or political factions, and no state institution should exercise influence over an election by identifying itself or taking sides with a particular political party or a candidate. The Court also viewed that the Korean president is a 'public official' under the Article 9 of the Public Officials Election Act ("POEA"). ${ }^{27}$

\footnotetext{
Constitutional Court of Korea, KCCR Vol. 16-1 (2004), 647-648.

Youngjae Lee, "Law, Politics, and," 412.

26 It says, "All public officials shall be servants of the entire Korean people and shall be responsible to the people."

27 The Court said, "A public official or a person who is obligated to maintain political neutrality shall not exercise any undue influence over an election or perform any act likely to affect the outcome of an election." Although it acknowledged the President maintains party membership after being elected as president and retains an affiliation with a political party, it held that the President should work for the entire nation and is obligated to unify the entire society, including those who supported him/her and those who opposed him/her as well. In this way, the Court found that the President violated the obligation to maintain political neutrality in elections by making the statements.

Constitutional Court of Korea, KCCR Vol. 16-1 (2004), 634-641.
} 
Political scientists harshly criticized this reasoning of the Court, saying that the Court's rationale completely misunderstood and ignored the dual status of the president: one as head of the administration and the other as a leader of a political party, and that if the Court's reasoning that President Roh should keep political neutrality in public officials' elections had been a reasonable decision, all the former presidents should have been impeached as well. ${ }^{28}$

Constitutional law scholars also criticized the Court's reasoning, saying that the President should not be categorized as a public official under Article 9 of the POEA who should keep political neutrality in elections, considering the political nature of the presidential office under pluralist democracy and that the president is a public official whose political activities are allowed under the State Officials Act, and other laws. ${ }^{29}$

\subsubsection{Reaction to the National Election Commission}

President's Press Secretary Lee Byung-Wan said on March 4, 2004, in response to a warning letter from the Commission, "I would like to make it clear that the Commission's decision is not persuasive at all," "Now we should change the election system and practice as our democracy advances," "The time when the president manipulated the state institutions to win election is now a thing of the past, and election laws should also be changed in line with the new election culture."

The Court found that the above statements were denigrating the current law as the 'vestige of the era of the government-interfered elections' and raising questions about the constitutionality and/or legality of the election law publicly do not conform to his obligation to abide by and protect the Constitution and other laws..$^{\circ}$

28 Myung-Lim Park, "Constitution, Constitutionalism, and Democracy in South Korea: Focusing on the Presidential Impeachment by the National Assembly in 2004," Political Scientists Society Review 39-1 (2005): 258-259.

29 Jong-Cheol Kim, "What Does the Korean Constitutional Court Miss or Misunderstand in The Impeachment Trial against President Roh Moo-Hyun?" World Constitutional Law Review 9 (2004): 14-17.

30 The Court also held that had the President tried to question the constitutionality of a bill passed by the National Assembly and believed that such a law be improved by revision, he should have asked for reconsideration by the parliament by returning the bill or by submitting a new bill with constitutionality issue being taken care of. Accordingly, the Court concluded that the statements by the Presidential Office, also called the Blue House were denigrating the current election law as a response to and in the context of the Commission's warning for violation 
Constitutional law scholars criticized the Court's ruling, saying that looking into the basic facts of the case, the President's Press Secretary mentioned first that the Commission's decision should be honored, and then expressed that there might be some disagreements over the interpretation of the relevant clauses of the election law additionally, thus the reaction by the Presidential office should not be interpreted as a violation of the rule of law principle. ${ }^{31}$

\subsubsection{Proposal for a National Referendum}

The third violation of law is about whether the President's proposal for a confidence vote as a referendum violates the Constitution. President Roh proposed a national referendum as vote of confidence in his presidency during his address at the National Assembly on October 13, 2003 by saying, "I announced last week that I would submit myself for public confidence. Although it may not be a matter that I am able to decide, I think a national referendum is a right way to implement that idea."

The Court held that Article 72 of the Constitution (referendum clause) does not allow a national referendum as a way to cast a confidence vote in the presidency, since that type of referendum is not expressly prescribed in the referendum clause. ${ }^{32}$ The Court concluded that although the President merely proposed an unconstitutional national referendum and did not follow up his proposal, mere proposal in itself is in violation of the Constitution, which is also not in conformity with the President's obligation to implement and protect the Constitution. ${ }^{33}$

\subsection{Grave Violation of Law and the Court's Strategic Positioning}

As we see from the above facts of the case, the violations found by the Court are basically remarks either by the President himself or his Press Secretary, whether

of the election law cannot be deemed as a proper attitude respecting law and order, rather being considered against the spirit of the rule of law and in violation of the President's obligation to protect the Constitution. Constitutional Court of Korea, KCCR Vol. 16-1 (2004), 647-648.

${ }^{11}$ Jong-Cheol Kim, "What Does the," 17-18.

32 It says, "The president may submit important policies relating to diplomacy, national defense, unification and other matters relating to the national destiny to a national referendum, if he deems it necessary."

33 Constitutional Court of Korea, KCCR Vol. 16-1 (2004), 648-650. 
it is an election related remark or a reactionary remark to the Commission or a referendum proposing remark, all of which are political in nature.

As for the election related remarks, the President was so keen on the upcoming general election and the parliamentary seat distribution after the election so as to make some remarks on the eve of the election in support of the Uri party despite expected fierce opposition, since if his party did not win the majority seats in the general election, his policies would be blocked in the parliament by the opposition. As for the lawmakers of both GNP and MDP parties who formed the super-majority in the lame-duck parliament, they were also very keen on the general election as to demand immediate apologies from the President for those remarks, since they all wanted to keep their seats and their party's share in the parliament. So all the activities involving the President and the opposition lawmakers on the eve of the election were inevitably very political in nature, striving to get or keep power in the parliament by getting the approval from the general public, which must be a core of the politics.

When it comes to the Constitutional Court, it had to pronounce its final decision on the impeachment motion against the President within a period of maximum six months since the reception of the case, ${ }^{34}$ especially under enormous pressure of the constitutional crisis as the presidential office was suspended for the first time in Korean history. It was in a very difficult position as a young Court (in its existence of some fifteen years) to be forced to decide whether to side with the impeaching parliament, dominated by the supermajority of the opposition parties of GNP and MDP, or to side with the impeached President, in this high profile case with paramount political implications. The Court finally took a very strategic position to partly side with the parliament by finding three violations by the President guilty but partly side with the President by dismissing the case in its entirety, which was only possible through the mechanism of 'grave violation of law' that was derived from its interpretations of Article 53 of the Constitutional Court Act (“CCA”), and Article 65 of the Constitution.

34 See Article 30 Section 1 of the Constitutional Court Act. 


\subsubsection{Court's Reasoning on 'Grave Violation of Law'}

(1) The Court's interpretation of Article 53 of the CCA

The Court begins with the interpretation of Article 53 of the CCA, which says, "When a request for impeachment is well founded, the Constitutional Court shall pronounce a decision to remove the respondent from his/her relevant public office." One interpretation of Article 53 of the CCA is that the Court shall automatically issue a removal decision as long as there is any legal ground for impeachment set forth in the impeachment clause (Article 65 of the Constitution), and according to that interpretation, the Court is bound to issue a removal decision upon finding any violation of law without regard to gravity of the violation. Should the respondent be removed from public office for any and all violation of law, however, it would be against the principle of proportionality that requires a balance between a violation and a punishment, according to the Court. Therefore the Court concluded that the existence of the 'well founded ground for request for impeachment' should mean the existence of a 'grave violation of law', sufficient to justify the removal of the President, not being merely any violation of law. ${ }^{35}$

The Court further noted that now the question is whether there is a grave violation of law or whether the removal of the President is justified in this case, and it should be determined by balancing the gravity of the violation of law and the impact of the removal decision, which is, balancing between the degree of the negative influence or harm caused by the violation of law upon the constitutional order and the impact to be caused by the removal decision. ${ }^{36}$

(2) What constitutes a grave violation of law?

The Court then said as follows:37 Although it is very difficult to describe in general terms what should constitute a grave violation of

\footnotetext{
Constitutional Court of Korea, KCCR Vol. 16-1 (2004), 654-655.

Constitutional Court of Korea, KCCR Vol. 16-1 (2004), 655.

Constitutional Court of Korea, KCCR Vol. 16-1 (2004), 655- 656.
} 
law, sufficient to justify the removal of the president, we should take into account that impeachment adjudication is designed to protect the Constitution/constitutional order from abuse of power on one hand, and that the removal decision would deprive the public's trust entrusted to the president on the other hand, and thus following two standpoints should be regarded as important standards.

From the first standpoint that impeachment adjudication is dedicated to the protection of the Constitution, a removal decision of the president may be justified only when the president's violation of law has a significant meaning in terms of protecting the Constitution and restoring the impaired Constitution/constitutional order by the removal decision. From the second standpoint that the president is a state institution representing the people's will directly entrusted with democratic legitimacy through election, a reasonable ground for impeaching the president should be found only when the president has lost the public trust by his/her violation of law so that the public may reclaim that trust during the tenure of the president. $3^{8}$

\subsubsection{Whether to Remove the President}

After elaborating its views on when to remove the president from office in general, the Court moved on to whether to remove the President in this case. It basically held that the remarks either by the President or his Press Secretary were made not in a way that was premeditated or willful, but in a way that was passive and incidental when answering reporters' questions or responding to the Commission, without the intention to stand against the

\footnotetext{
${ }^{8}$ The Court added: Now to be more specific, the constitutional order, which is designed to be protected by the impeachment adjudication should mean the 'basic order of liberal democracy', which consists of the two principles, rule of law and democracy. The key elements of rule of law are respect for human rights, separation of powers, and independence of judiciary, and the essential elements of democracy are parliamentary system, multi-party system, and public officials' election. Thus a violation of law viewed from the first standpoint of protecting the Constitution/constitutional order means a violation of law threatening the basic order of liberal democracy, which means a 'willful violation' of the fundamental principles of rule of law and democracy. From the second standpoint of the public trust, an act that betrays the public trust entrusted to the President means other violations of law of him/her that may not threaten the basic order of liberal democracy, whose typical examples include bribery, corruption, and other acts obviously harming state interests. Constitutional Court of Korea, KCCR Vol. 16-1 (2004), 656.
} 
basic order of liberal democracy or against the rule of law principle (the first and the second violations), and that the confidence vote proposal (the third violation) was merely a proposal during his speech at the National Assembly, not being considered a willful violation of the fundamental principles of the Constitution such as democracy, nor to have caused a significant harm to the constitutional order.

\subsubsection{Understanding 'Grave Violation of Law' Logic}

The Constitutional Court made it clear through its ruling that the impeachment adjudication is solely to determine whether a ground for impeachment exists from a legal perspective, and it is the Court's task, not the legislatures' to make a final decision on presidential impeachment. ${ }^{39}$ And as noted in the above, what the Court basically said in this case is that in order to remove the President from office, first there must be a violation of law, and second the violation of law must be grave enough to remove him/ her from office, both of which are legal judgments, not an issue politically decided.

I believe that by establishing 'grave violation of law' rationale, the Court was able to pronounce that the removal decision is solely at the discretion of the Court, dismissing the Roh impeachment case in its entirety and reclaiming the presidency after all, even after finding a couple of violations of law by the President guilty ${ }^{40}$, since whether there is a grave violation of law is a legal judgment belonging to the Court, not to a political institution like parliament, according to the Court's rationale. Then the question arises where this idea of 'grave violation of law' comes from? One possibility might be from the idea of "high crimes and misdemeanors" in the U.S. Constitution. ${ }^{4}$

39 Constitutional Court of Korea, KCCR Vol. 16-1 (2004), 654.

40 The idea that the Court has a discretion to remove or not to remove the President even when he/she is found to have violated the Constitution, might come from or at least be influenced by Article 56 Section 2 of the Act on Federal Constitutional Court of Germany, which says, "In the event of a conviction, the Federal Constitutional Court may declare that the Federal President has forfeited his or her office."

${ }_{41}$ Jin-Wook Kim, "An Essay on Grounds for Impeachment," State and Constitution I (2018), 1717-1719, Bobmun Sa. 


\subsubsection{Court's Strategic Positioning}

As it may be seen from the background of this case and the Court's findings above, this impeachment case is comparable to President Johnson's impeachment in 1868 in the United States.

President Johnson, who succeeded President Lincoln as vice-president after Lincoln's assassination in 1865, had conflicts with the majority of his own Republican members, so called the Radicals, who controlled both Houses of the parliament, trying to keep their own Reconstruction policies over the South, which Johnson opposed. Johnson wanted to remove Edward Stanton, the Secretary of War who was in charge of the military reconstruction policy and also a Radical, but the Congress passed the Tenure of Office Act in 1867, aimed to make the Secretary's removal dependent upon the consent of the Senate, over Johnson's veto. Johnson's immediate dismissal of Stanton enraged the Radicals and the impeachment against President Johnson was filed in the Congress, but he escaped conviction in the Senate by one vote in $1868.4^{22}$

As the Johnson impeachment which began with differing views on key policies such as the Reconstruction of the South and a power struggle between the President and the majority of his own Republican Party, was obviously a politically motivated impeachment, the Roh impeachment also began with a power struggle in his own party and became a political weapon for the opposition to use, to deter the President's political speeches on the eve of the general election.

One key thing to understand the Roh impeachment is that the impeachment itself was so unpopular that seven out of ten Koreans were against it, and there were nation-wide demonstrations protesting the impeachment filing by the parliament. Naturally the presidential impeachment became a key campaign issue in the April 2004 general election in the middle of the impeachment trial, which it turned out that

42 Berger, Raoul, Impeachment: The Constitutional problems (London: Harvard University Press, 1973), 252-263. The removal consent clause of the Tenure of Office Act was held unconstitutional by the U.S. Supreme Court later in Myers v. United States (1926). 
the President's Uri party won the majority by more than tripling their seats in the National Assembly. ${ }^{43}$ The Presidential impeachment in March and the general election and the ruling party's unexpected win in April and the Constitutional Court's dismissal of the impeachment in May, 2004 were such a quick turn of events in terms of political dynamics. I believe that it was a wise decision for the Court to dismiss the impeachment in its entirety, even after finding three violations guilty through the mechanism of the grave violation of law, and that as long as the decision whether there is a grave violation of law in impeachment case is a legal decision that should be decided by the Court, I suppose that the Constitutional Court can always make a strategic decision even in this sort of highly political case, in terms of political dynamics between state institutions of the Korean government

When it comes to the internal political dynamics within the Court, a reporter who covered the impeachment case from beginning to end revealed that there had been three unpublished dissenters with the opinion that the three counts of the President's violations were grave enough to remove him from the presidency. ${ }^{44}$ I think that the existence of three those dissenters might explain why the Court developed the 'grave violation of law' logic in this case, since through that mechanism, I believe the Court was able to find some violations guilty but still dismiss the case after all.

\subsubsection{Legal Issues with the Grave Violation of Law Logic}

Although the grave violation of law logic itself may not be that unique, but what constitutes 'grave violation' is very unique in the Roh impeachment case, having some legal issues that should be dealt with.

The first issue in the 'grave violation of law' requirement might be that the Court did not make any difference between a violation of the Constitution and a violation of other statutes. While violations of statutes might greatly vary from a violation of the criminal code with a possibility of heavy penalty, such as bribery to a minor violation, such as traffic violation, a violation of

43 Youngjae Lee, "Law, Politics, and Impeachment," 412.

44 Lee, Beom-Jun, Constitutional Court: Tells about Korea's recent history, (KungRee, 2009), 357-359. 
the Constitution should be different in nature and weight from a violation of a statute, since if the Constitution is found to be violated, the gravity of the violation may not be comparable to a minor violation of a simple statute, to the degree that we can even say that if there is a violation against the Constitution, the gravity of the violation is presumed.45 Considering that the idea of "high crimes and misdemeanors" in the U.S. Constitution originally meant the crimes and misdemeanors against the state or against the United States, ${ }^{46}$ a violation against the Korean Constitution can be easily understood as a violation against the Republic of Korea and thus presumably a grave violation.

In this sense, it is understandable that when the Constitutional Court discussed the gravity of the violation, the first standpoint/standard should be the constitutional order, and the gravity should be estimated by assessing the damage or harm done upon the order by the President. But the problem is that the Court equated the constitutional order with the 'basic order of liberal democracy' without any further explanation, which is the same standard to be applied in the dissolution of the political party. Since the 'basic order of liberal democracy' only includes the rule of law and democracy according to the Constitutional Court's precedents, if the constitutional order has such a limited meaning, it seems that the first standard/standpoint, established in relation to the constitutional order, is too narrow, ${ }^{47}$ which might show some reluctance of the Court to remove the President in this case.

Another issue in the Court's rationale is that while the Court said that a grave violation of law from the first standpoint, which is equated with the basic order of liberal democracy, means a 'willful violation' of the rule of law and democracy, the reason why only the 'willful violation' can be a grave violation is not clear.

45 Jin-Wook Kim, "The Grounds for Presidential Impeachment under the Korean Constitution," The Justice 161 (2017): 18-19, The Korean Legal Center.

46 Cass Sunstein, "Impeaching the President," University of Pennsylvania Law Review 147 (1998): 285-289.

47 Ha-Yeol Kim, "Presidential Impeachment - 2017.3.10. 2016Hun-na1 decision," Beobjo 722 (2017), 410-411, Beobjo Association. 
Some critics pointed out that the grave violation rationale began with a different interpretation of Article 53 of the Constitutional Court Act from that of Article 65 of the Constitution, simply mentioning, "a violation of the Constitution and/or other statutes" as grounds for impeachment, asserting that both grounds for impeachment in the Constitution and the Act cannot be different but the same, and that the grave violation logic by the Court is unnatural and unreasonable. ${ }^{48}$ I suppose that the idea of the 'willful violation' requirement might come from or at least be influenced by Article 56 Section 1 of the Federal Constitutional Court Act of Germany, which says, "The Federal Constitutional Court shall declare in its judgment whether the Federal President is guilty of intentionally violating the Basic Law or a federal law, which must be clearly specified."

The last issue with the Court's grave violation analysis is that even though the Court elaborated on the second standpoint that the President is a state institution entrusted with democratic legitimacy through a national election, the Court just briefly mentioned that the President has not betrayed the Korean people's trust entrusted to him through election from the second perspective, but failed to provide any reasoning why the President had not betrayed the public trust in this case.

\section{ANALYSIS OF THE PRESIDENT PARK IMPEACHMENT CASE}

\subsection{Background of the Case 49}

The political scandal or crisis that led to the impeachment of President Park Geun-Hye ${ }^{50}$ went back to the press report in late July, 2016 concerning the contributions to the Mir and K-Sports Foundations by some Chaebols (large business conglomerates) such as Samsung and Hyundai. The presidential office, also called the Blue House was reportedly involved deeply in the establishment of those two sports related foundations, which is quite unusual.

$4^{8}$ Lee, Seung-Woo, "Case Study on President Roh's impeachment", Constitutional Decision's Study 6 (Korean Constitutional Decision's Study Society, 2004), 288-290.

49 This background of the case comes mostly from the Court's ruling at Constitutional Court of Korea, KCCR Vol. 29-1 (2017), 9-10.

50 Park Geun-Hye, a daughter of former President Park Chung-Hee, a military dictator, was elected as president in late 2012. 
In the midst of the scandal, there came a decisive report on October 24 that key Blue House documents had been leaked to President Park's old confidante Mrs. Choi Sun-Sil ("Mrs. Choi"), and that she had intervened in state affairs completely behind the scene. The news immediately shocked the nation, and public sentiment began to turn its back on the President, condemning her connection with Mrs. Choi. The next day, President Park delivered a national address saying, "I admit that I had taken Mrs. Choi's advice from time to time on some wordings of my speeches or PR documents, but I dropped that practice after the Blue House secretarial office was fully staffed. It all began from good intentions, but if it caused any trouble to the people, I now want to make my sincere apologies."

Despite that national address, there came out other reports on Mrs. Choi's secret intervention in state affairs, and on November 3, she was arrested just after returning to Korea from Germany, on charges of abuses of power and other allegations. On the next day, President Park had to deliver a second national address, offering her second apology to the effect that she is even willing to take her own responsibility, if any.

On November 6, her Senior Secretary for Policy Coordination, Ahn JongBeom, was arrested on charges of attempted coercion and abuses of power, and her Secretary for Personal Affairs, Mr. Chung was also detained for allegedly leaking secret documents to Mrs. Choi. They were indicted on November 20, and a few days later, the opposition parties agreed to jointly draft and submit a motion to impeach the President. At that, President Park offered her third apology on November 29, and said, "I will leave it up to the National Assembly whether I should resign from or remain in office, and whether my remaining term as president should be shortened."

Despite her willingness to resign from the presidency in accordance with the National Assembly's decision, the parliament launched a special committee to conduct an investigation into suspicions that a civilian had secretly intervened in state affairs, and an independent counsel to conduct criminal investigation into that matter was appointed by the President immediately. On December 3, 171 
lawmakers submitted a motion for presidential impeachment, and it was passed with the super-majority of 234 members of the parliament voting in favor of the impeachment (out of 300 total members) on December 9, 2016.

\subsection{Court's Findings on Park's Violations}

After deliberation, the Court found that Park violated the Constitution and other statutes on the following three instances. Those are in essence, the violation of the obligation to serve public interests and stay away from special interests, the infringement on the property rights and freedom of business of some Chaebol companies by abusing her presidential power, and the violation of duty to confidentiality.

First, the Court found that the President appointed a number of people referred by Mrs. Choi to key government positions, including the Minister of Culture, Sports, and Tourism, and some appointees, by using their positions and power, helped Mrs. Choi to pursue her own personal gains. ${ }^{51}$ The President also appointed, at Mrs. Choi's referral, Kim Jong-Duk, Mr. Cha's college professor to the Minister of Culture, Sports, and Tourism, and Kim Jong-Ryul, Mr. Cha's uncle, to the President's Senior Secretary for education and culture. Kim Jong from time to time sent his ministry's classified documents to Mrs. Choi and tried to incorporate her comments into the policies of the ministry. ${ }^{52}$

The Court further found that President Park instructed her staff, including her Senior Secretary for Economic Affairs, Ahn Jong-Beom that Mir and K-Sports foundations should be established by being contributed by some Chaebol companies abusing her presidential power, but they were not able to involve in the management of the foundations at all, even if they funded all the money, whereas Mrs. Choi did involve in the management of the two foundations from the beginning to the degree that the executives and the staff called Mrs.

\footnotetext{
51 For example, at the referral of Mrs. Choi, President appointed Kim Jong, a professor majoring in sports industry to vice Minister of the Ministry of Culture, Sports, and Tourism, and appointed Cha Eun-Taek, who ran an advertisement agency, to a member of the Presidential Committee for Cultural Advancement, and later became the head of the Creative Center for Cultural Convergence with the help of Mrs. Choi.

52 Constitutional Court of Korea, KCCR Vol. 29-1 (2017), 25.
} 
Choi the Chairperson, working under her instructions. Mrs. Choi also had the foundations enter into many business dealings with her companies such as Playground (advertising company), the Blue K (sports management company), both of which were under her ownership and control.

President Park had been involved even in the management of some private companies such as KT (a leading telecommunication company in Korea) and Hyundai Motor Company by asking for the employment of Mrs. Choi's acquaintance or for signing contracts with Mrs. Choi's companies like Playground.53

Upon those findings, the Court held that President Park had violated Article 7 of the Constitution, which it interpreted that public officials shall be independent from special interests of a political party or a group he/she belongs to, and other statutes which are in line with Article 7 of the Constitution ${ }^{54}$, by abusing her presidential power for the purpose of giving favor to Mrs. Choi and/ or other her close associates. 55

The second was the infringement on the property rights and freedom of business of the private companies. Citing that President Park either in person or via the Senior Secretary for Economic Affairs, Mr. Ahn requested that some Chaebol companies such as Samsung, Hyundai Motors, SK group, LG group etc. make contributions to establish Mir and K-Sports foundations, and considering the president's extensive power and influence in the financial and economic sectors, and the unusual way through which the foundations were established and managed, those contribution requests are tantamount to coercion, not a voluntary cooperation, which in turn are estimated as a violation of property rights and freedom of business of those companies.

The Court also found that President Park interfered with the management of private companies by asking KT to hire Mrs. Choi's referral or demanding Hyundai Motor Company to sign a supply contract with a company run by Mrs. Choi's acquaintance, concluding that the President infringed upon the property

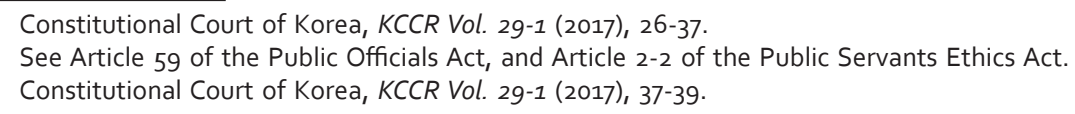


rights and freedom of business of those companies by abusing her presidential power. $5^{6}$

The third was the violation of the duty to confidentiality, which is prescribed in Article 60 of the State Officials Act ${ }^{57}$. The Court mentioned that the presidency has many occasions when becoming aware of classified government information in the course of making high-level policy decisions, and pointed out that numerous government documents were leaked to Mrs. Choi under the President's instruction or acquiescence, whose information includes the President's schedules, foreign policies, and government's personnel matters, etc., which may well be classified as 'official secrets'.

\subsection{Whether to Remove the President}

The Court in this case basically followed the 'grave violation of law' rationale in the Roh impeachment precedent, which weighs the gravity of the violation from the two perspectives, concluding as follows:

The President repeatedly allowed Mrs. Choi to interfere with state affairs while keeping it a complete secret, and when suspicions arose that the President was heeding the advice of powerful secret aids like Mrs. Choi, on several occasions, she continued to deny it in its entirety. Thus the President's conduct, which allowed Mrs. Choi's interference and pursuit of her own interests, and kept it a complete secret, has undermined the principle of representative democracy and the rule of law, and amounts to a grave violation of her duty to serve the public and stay away from special interests.

The President, however, did not make any effort to regain the public trust, but repeatedly made meaningless apologies to the Korean people, failing to keep her own word, so that it is difficult to find any definite will on the part of the President to protect the Constitution.

To conclude, the President's violation of the Constitution and other statutes should be considered a grave violation of law that cannot be condoned from the

56 Constitutional Court of Korea, KCCR Vol. 29-1 (2017), 39-40.

57 According to the article, public officials must keep the information confidential that they became aware of in the course of performing his/her official duties. 
perspective of protecting the Constitution, which is also regarded as a betrayal of the public trust. The negative impact caused by the President's violations of law is so serious that the benefits of removing the President for the purpose of protecting the Constitution may well overwhelmingly outweigh the national loss incurred by the removal decision.

\subsection{Grave Violation of Law and the Court's Positioning}

\subsubsection{Court's Reasoning on 'Grave Violation of Law'}

While the Court in this case basically followed the 'grave violation of law' rationale in the Roh impeachment precedent, which weighs the gravity of the violation from the two perspectives, it did not lump together a violation of the Constitution and a violation of a statute, different from the Roh decision. Although the motion to impeach President Park involved five counts of violations of the Constitution including the violation of the principle of representative democracy and the rule of law, and eight criminal violations including bribery and abuses of power,,$^{8}$ the Court tried to accelerate the impeachment trial despite opposition from the President's lawyers and render a final decision as soon as possible in order to shorten the power vacuum due to the suspension of the presidential office incurred by the passage of the impeachment motion on December 9, 2016.

The Court handed down its final decision on impeachment on March 10, 2017 after holding three preparatory hearings and seventeen oral hearings, calling twenty-six witnesses and examining and cross-examining them within three months' impeachment trial, which taken together was a great workload completed within a relatively short amount of time. ${ }^{59}$ Like the President Roh case, the Court acknowledged that all three counts of President Park's violations that were found to be guilty constitute grave violations of law, citing the two standpoints/perspectives, among which the first standpoint is that impeachment adjudication is a procedure dedicated to protecting the Constitution/constitutional order, and the second perspective is that

\footnotetext{
Constitutional Court of Korea, KCCR Vol. 29-1 (2017), 10-14.

Constitutional Court of Korea, KCCR Vol. 29-1 (2017),14.
} 
the President is a representative institution to which the public has directly entrusted democratic legitimacy. ${ }^{60}$ Thus the criticism set forth in the Roh case against the grave violation rationale should be still valid in this case as well.

One thing to note is that the Court did not mention or examine whether there was a 'willful violation' of the 'basic order of liberal democracy' when discussing the grave violation of law in this case, especially from the first perspective, and I suppose that might be seen as a progress in terms of the reasoning of the Court. ${ }^{61}$

Another thing to note in this decision is that even though the Court goes after the Roh impeachment precedent in following the grave violation logic by citing the two standards/perspectives, it did not clearly announce which standard/perspective is considered in the assessment of the grave violation requirement when concluding this case, and it seems that the Court chose to say rather vaguely to the effect that this case may well satisfy both standards in terms of the assessment of the gravity requirement, as opposed to the previous Roh impeachment case. ${ }^{62}$

\subsubsection{Court's Strategic Positioning}

As it may be seen from the background of this case and the Court's findings above, this impeachment case is comparable to President Nixon's impeachment in 1974 in the United States since both cases involve serious abuses of presidential power during office. Even though President Nixon resigned from his office just after the articles of impeachment against him were passed by the House Judiciary Committee on July 27, 1974, he is believed to be removed from his office if he is tried in the Senate, considering the gravity of his violations, especially in terms of "high crimes and misdemeanors" in the U.S. Constitution to the degree that all three counts of the violations of the articles end like this: "In all of this, Richard M. Nixon has acted in a manner contrary to his trust as President and subversive of constitutional

\footnotetext{
Constitutional Court of Korea, KCCR Vol. 29-1 (2017), 20-21.

Jin-Wook Kim, "The Grounds for Presidential Impeachment under the Korean Constitution," 25-27.

Jin-Wook Kim, "The Grounds for Presidential Impeachment under the Korean Constitution", 38-39.
} 
government, to the great prejudice of the cause of law and justice and to the manifest injury of the people of the United States." ${ }^{3}$

I suppose that the two points summarized in the above conclusion of the articles of impeachment for Nixon well describe the two standards or perspectives of the grave violation requirement in the Korean impeachment precedents, one of which is the subversion of constitutional government or the great prejudice of the cause of law and justice (which might be equivalent to the first standard/perspective in both the Roh and Park cases), and the other of which is the betrayal of public trust or the manifest injury of the public (which might be equivalent to the second standard/perspective in both cases).

Unlike the Roh case, in terms of political dynamics involving the Korean public, the motion to impeach President Park was so popular that more than 80 percent of the Korean population supported the impeachment ${ }^{64}$ and the President became so unpopular that her approval ratings dropped to about 5 percent around the impeachment motion ${ }^{65}$ and even her own party's many lawmakers decided to turn their back to approve the impeachment. That might explain the 8:0 impeachment decision on March 10, 2017 by the Constitutional Court (after the Chief Justice left the Court due to his tenure expiration), which I believe was a strategic positioning as it is in line with the supermajority of the Korean public.

With regard to the second standard/perspective about the betrayal of public trust, even though the Court set that standard to assess the grave violation of law against the President as if it were a purely legal matter, it may not be a legal judgment but a factual (political) judgment, if the will of the people should be considered. Thus if the Court makes a decision on presidential impeachment by using that standard/perspective, it is to be considered a political judgment rendered by the Court, not on its own but

\footnotetext{
3 See the full text of the Articles of Impeachment adopted by the House Judiciary Committee on July 27, 1974.

"86\% of public approves of Park's impeachment," Korea Herald, March 10, 2017.

65 "Park's approval rating remains at record low," Korea Herald, December 2, 2016.
} 
on behalf of the general public, and only in that case, the Court's judgment may be justified both legally and politically. ${ }^{66}$

\section{CONCLUSION}

The recent two impeachment cases decided by the Constitutional Court of Korea, respectively in 2004 against President Roh and in 2017 against President Park might be classic examples of how the state institutions including the Court interact with other institutions in a very political case like presidential impeachment, in terms of political dynamics.

In the impeachment case against President Roh, the Court positioned itself strategically by establishing the 'grave violation of law' rationale, where it sided with the impeaching parliament by finding three counts of violations of law but dismissed the case in its entirety through the operation of the 'grave violation of law', which might show its reluctance to remove the president. In the impeachment case against President Park, the Court basically followed the grave violation logic but reached a different conclusion to remove the President, which might be another strategic position taken by the Court, which is in line with the will of the super-majority of the Korean public.

\section{BIBLIOGRAPHY}

Ahn, Kyong-Whan. "The Influence of American Constitutionalism in Korea." Southern Illinois Law Journal 22 (1997).

Berger, Raoul. Impeachment: The Constitutional Problems. London: Harvard University Press, 1973.

Constitutional Court of Korea. Thirty years of the Constitutional Court of Korea. South Korea: Constitutional Court of Korea, 2018.

Gerhardt, Michael. The Federal Impeachment Process. Chicago: The University of Chicago Press, 2000.

$\overline{66}$ Jin-Wook Kim, "An essay on grounds," 1725-1728. 
Kim, Ha-Yeol. "Presidential Impeachment - 2017.3.10. 2016Hun-na 1 decision." Beobjo 722 (2017). Beojo Association.

Kim, Jin-Wook. "The Grounds for Presidential Impeachment under the Korean Constitution." The Justice 161 (2017). The Korean Legal Center.

Kim, Jin-Wook, "An Essay on Grounds for Impeachment." State and Constitution I (2018). Bobmun Sa.

Kim, Jin-Wook."Freedom of Business under the Korean Constitution.” Business Finance Law 54 (2012). Center for Financial Law of Seoul National University. Kim, Jong-Cheol. "What Does the Korean Constitutional Court Miss or Misunderstand in the Impeachment Trial against President Roh Moo-Hyun?" World Constitutional Law Review 9 (2004).

Lee, Beom-Jun. Constitutional Court: Tells about Korea's recent history. Seoul: Kungree, 2009.

Lee, Youngjae."Law, Politics, and Impeachment of Roh Moo-Hyun from a Comparative Constitutional Perspective." American Journal of Comparative Law 53 (2005).

Lin, Chien-Chih. "Pace of Constitutional Transition Matters: The Judicialization of Politics in Indonesia and Korea." UCLA J. INT'L L. E FOR. AFF 2o, (2016). Park, Jonghyun. “The Judicialization of Politics in Korea." Asian-Pacific Law E Policy Journal 10 (2008).

Park, Myung-Lim. "Constitution, Constitutionalism, and Democracy in South Korea: Focusing on the Presidential Impeachment by the National Assembly in 2004." Political Scientists Society Review 39-1 (2005).

Posner, Richard. An Affair of State: The Investigation, Impeachment, and Trial of President Clinton. (London: Harvard University Press, 2000).

Sunstein, Cass. "Impeaching the President." University of Pennsylvania Law Review 147, (1998). 